\title{
Sosialisasi Pelaksanaan Proyek Pelatihan Sistem Filterisasi Air Payau Menjadi Air Siap Konsumsi pada Kantor Pemberdayaan Masyarakat Desa Maros
}

\author{
Muh Anshar*, Elyas Palantei, Zaenab, Dewiani, Andreas Vogel, Rhiza S. Sadjad \\ Departemen Elektro, Fakultas Teknik UNHAS \\ anshar@unhas.ac.id*
}

\begin{abstract}
Abstrak
Kesuksesan pelaksanaan proyek air bersih "QECeWaS 1" yang menitikberatkan pada tiga kegiatan utama telah menjadi momentum pelaksanan awal kegiatan sosialisasi diawali dengan kunjungan tim pengabdian ke kantor Dinas Pemberdayaan Masyarakat Desa Kabupaten Maros yang terlaksana pada 7 Juni 2018. Diskusi melingkupi dan menjajaki kemungkinan desa-desa yang memiliki permasalahan terkait air bersih, seperti pada Desa Tellumpoccoe yang menjadi target daerah untuk kegiatan QECeWaS 1 sebelumnya. Langkah selanjutnya dalam kegiatan proyek QECeWaS 2 yang menjadi target utama dalam artikel ini adalah pelaksanaan sosialisasi secara langsung dengan kepala-kepala desa termasuk, kedua desa yang telah bersepakat memainkan andil pada proyek ini. Pihak Dinas Pemberdayaan Masyarakat Desa (PMD) Kabupaten Maros telah mengundang sembilan desa, termasuk Desa Nisombali dan Bonto Bahari; dan sekitar tujuh kepala desa yang berkesempatan hadir pada kegiatan sosialisasi yang berlangsung pada 22 November 2018 di Kantor Dinas PMD Kabupaten Maros. Respon positif terhadap kegiatan proyek QECeWaS 2 nantinya dapat berlangsung dengan lancar dan memacu desa lain untuk bergabung dalam kegiatan tersebut.
\end{abstract}

Kata Kunci: Filterisasi; QECeWas 2; Reverse Osmosis; Salinitas; PMD.

\section{Pendahuluan}

Kesuksesan pelaksanaan proyek air bersih "QECeWaS 1" yang menitikberatkan pada tiga kegiatan utama, yaitu: (1) pelaksanaan seminar sehari dengan titik berat pada air bersih; (2) pelaksanaan pelatihan selama dua hari terkait perakitan sistem air filterisasi air bersih, operasional dan pemeliharaan peralatan serta (3) penginstalasian sistem filterisasi air bersih untuk skala besar yang dapat diakses oleh masyarakat luas, telah memberikan dampak positif tidak hanya terhadap masyarakat dimana proyek QECeWaS 1dilaksanakan akan tetapi merambah ke badan pemerintahan kabupaten. Hal ini menjadikan momentum khususnya Dinas Pemberdayaan Masyrakat Desa Kabupaten Maros untuk mengundang masyarakat yang berada pada desa-desa di kabupaten Maros yang notabene mengalami permasalahan yang sama dan untuk mengambil bagian pada pelaksanaan kelanjutan dari proyek QECeWaS 2 mendatang.

\section{Sekilas tentang Proyek QECeWaS 1}

Proyek QECeWaS 1 yang telah dilaksanakan berlangsung di Desa Tellumpoccoe, Kecamatan Marusu, Kabupaten Maros Sulawesi Selatan memiliki dua titik prioritas pengembangan, yaitu air dan kesehatan masyarakat. Terdapat beberapa hal-hal penting yang telah dicapai selama pengimplementasian proyek tersebut, yaitu:

(1) Dua kegiatan utama, seminar sehari dan pelatihan dua hari berlangsung dengan sukses, dimana kegiatan tersebut secara resmi dibuka oleh Konsulat Jenderal Australia untuk Indonesia di Makassar, Bapak Richard Matthews. Target 25 peserta tercapai selama kegiatan dan ditandai dengan terbentuk tim teknis untuk proses instalasi air berskala besar nantinya. 
(2) Instalasi air bersih skala besar untuk masyarakat umum yang memanfaatkan teknologi sistem filter air Reverse Osmosis (RO) berhasil dilaksanakan dan beroperasi secara sempurna. Masyarakat sudah dapat memperoleh air siap minum secara gratis.

(3) Peningkatan kesadaran masyarakat sekitar tentang pentingnya mengkonsumsi air bersih untuk air minum secara rutin tiap hari, khususnya masyarakat yang berada disekitar sistem filter air. Hal ini ditandai dengan meningkatnya animo masyarakat dalam mengambil air dalam wadah penyimpanan untuk kemudian diangkut ke rumah masing-masing

(4) Peningkatan kesadaran memelihara sistem air bersih yang ditandai dengan terbentuknya grup diskusi berbasis online yang didedikasikan untuk sustainabilitas dari prototipe air bersih, termasuk merekrut peserta baru untuk proses transfer knowledge terkait aspek teknis dari sistem filter air bersih.

(5) Dengan dibekalinya masyarakat sekitar dengan peralatan untuk mengukur kualitas air, dalam hal ini TDS meter, kesadaran untuk selalu memonitor kualitas air untuk konsumsi agart selalu memenuhi standar sehat untuk air minum semakin meningkat.

\section{Standarisasi Air Layak Konsumsi}

Mengacu pada Peraturan Menteri Kesehatan Republik Indonesia Nomor 429/Menkes/PER/IV/2010 (MENKES RI, 2010) terkait persyaratan kualitas air minum dan pada artikel (anshar et al. 2018), terdapat beberapa persyaratan yang hendaknya dipenuhi, meliputi:

\subsection{Persyaratan Fisik}

Persyaratan fisik yang harus dipenuhi pada air minum yaitu harus jernih, tidak berbau, tidak berasa dan tidak berwarna. Sementara suhunya sebaiknya sejuk dan tidak panas. Selain itu, air minum tidak menimbulkan endapan. Jika air yang kita konsumsi menyimpang dari hal ini, maka sangat mungkin air telah tercemar.

\subsection{Persyaratan Kimia}

Dari aspek kimiawi, bahan air minum tidak boleh mengandung partikel terlarut dalam jumlah tinggi serta logam berat (misalnya $\mathrm{Hg}, \mathrm{Ni}, \mathrm{Pb}, \mathrm{Zn}$, dan $\mathrm{Ag}$ ) ataupun zat beracun seperti senyawa hidrokarbon dan detergen. Ion logam berat dapat mendenaturasi protein, disamping itu logam berat dapat bereaksi dengan gugus fungsi lainnya dalam biomolekul. Karena sebagian akan tertimbun di berbagai organ terutama saluran cerna, hati dan ginjal, maka organ-organ inilah yang terutama dirusak.

\subsection{Persyaratan Mikrobiologis}

Bakteri patogen yang tercantum dalam Kepmenkes yaitu Escherichia Colli, Clostridium Perfringens, Salmonella. Bakteri patogen tersebut dapat membentuk toksin (racun) setelah periode laten yang singkat yaitu beberapa jam. Keberadaan bakteri Coliform (E.Coli tergolong jenis bakteri ini) yang banyak ditemui di kotoran manusia dan hewan menunjukkan kualitas sanitasi yang rendah dalam proses pengadaan air. Makin tinggi tingkat kontaminasi bakteri coliform, makin tinggi pula risiko kehadiran bakteri patogen, seperti bakteri Shigella (penyebab muntaber), S. Typhii (penyebab Typhus), Kolera, dan Disentri. 


\section{Teknologi Reverse Osmosis}

Teknologi yang digunakan akan memanfaatkan teknologi desalinasi air berbasis Reverse Osmosis, seperti halnya teknologi yanhg digunakan pada implementasi proyek QECeWaS 1. Teknologi ini memanfaatkan membran untuk memfilter partikel-partikel yang berada dalam ukuran sangat kecil (mikron). Pembahasan lebih detail terkait teknologi RO dapat diperlihatkan pada artikel (Kucera, J. 2010). Contoh desain ukuran filter berbasis Reverse Osmosis dapat diperlihatkan pada Gambar 1 berikut ini.

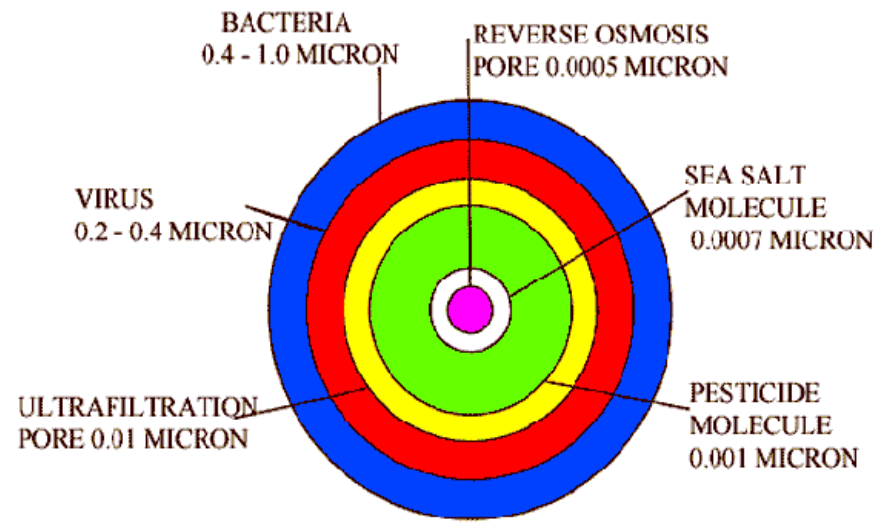

PORE SIZE COMPARED WITH MOLECULES, BACTERIA AND VIRUS APROXIMATE VALUES AND FIGURE IS NOT TO SCALE

\section{Gambar 1. Ukuran Filter Reverse Osmosis}

\section{Pra Kegiatan Sosialisasi}

Pelaksanan awal kegiatan sosialisasi diawali dengan kunjungan tim pengabdian ke kantor Dinas Pemberdayaan Masyarakat Desa Kabupaten Maros yang terlaksana pada 7 Juni 2018. Diskusi melingkupi dan menjajaki kemungkinan desa-desa yang memiliki permasalahan terkait air bersih, seperti pada Desa Tellumpoccoe yang menjadi target daerah untuk kegiatan QECeWaS 1 sebelumnya. Terdapat sekitar sepuluh desa pada Kabupaten Maros yang memiliki permasalahan akses air bersih dimana sumber air yang tersedia adalah air payauh atau air dengan tingkat salinitas yang sangat tinggi, dimana desa-desa tersebut berada pada daerah pesisir pantai.

Proses selanjutnya mengkomunikasikan hasil diskusi tersebut dengan desa-desa yang telah diinventaris tersebut dan terdapat dua desa, Desa Nisomnbalia dan Bonto Bahari yang memberikan respon positif untuk bergabung dalam kegiatan proyek QECeWaS 2. Kedua desa ini berada pada dekat dekat pesisir pantai dan sebagian besar masyarakat pada kedua desa tersebut memiliki akses terhadap air bersih sangat minim. Terutama pada musim kemarau, masyarakat pada kedua desa tersebut menempuh jarak yang jauh dengan mengambil sumber air tawar dari Kota Makassar. 


\section{Pelaksanaan Sosialisasi Pelatihan Sistem Filterisasi Air Payauh Menjadi Air Siap Minum}

Langkah selanjutnya dalam kegiatan proyek QECeWaS 2 yang menjadi target utama dalam artikel ini adalah pelaksanaan sosialisasi secara langsung dengan kepala-kepala desa termasuk, kedua desa yang telah bersepakat memainkan andil pada proyek ini.

Pihak Dinas Pemberdayaan Masyarakat Desa (PMD) Kabupaten Maros telah mengundang sembilan desa, termasuk Desa Nisombali dan Bonto Bahari; dan sekitar tujuh kepala desa yang berkesempatan hadir pada kegiatan sosialisasi yang berlangsung pada 22 November 2018 di Kantor Dinas PMD Kabupaten Maros. Adapun ketujuh desa tersebut adalah sebagai berikut:

- Desa Nisombalia

- Desa Bonto Bahari

- Desa Minasa Upa

- Desa Salenrang

- Desa Bontolmpangan

- Desa Salenrang

- Desa Ampekale

Dari ketujuh desa tersebut, Desa Nisombalia dan Bonto Bahari menjadi prioritas utama kegiatan mengingat antusiasme yang tinggi dari kedua desa tersebut yang telah dituangkan dalam bentuk Surat Kesediaan Berpartisipasi dalam kegiatan proyek QECeWaS 2. Foto sosialisasi kegiatan dapat diperlihatkan pada Gambar 2(a) sampai Gambar 2(f) berikut ini.

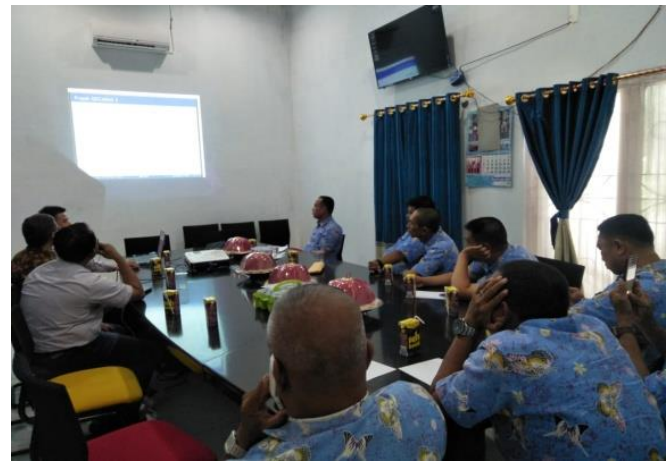

Gambar 2(a). Sosialisasi Awal

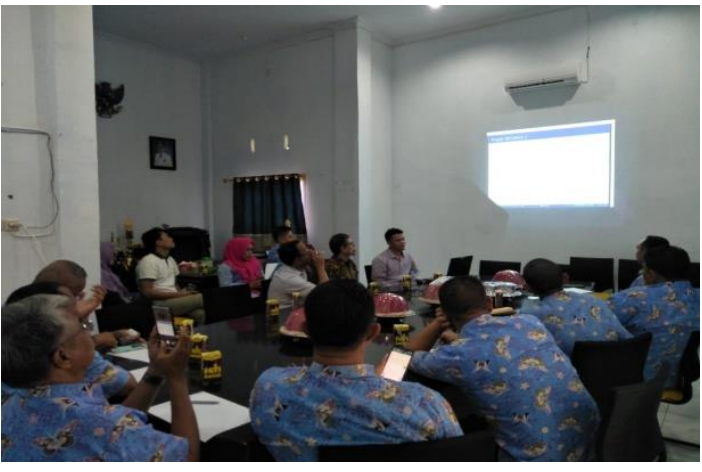

Gambar 2(b). Sosialisasi Awal 


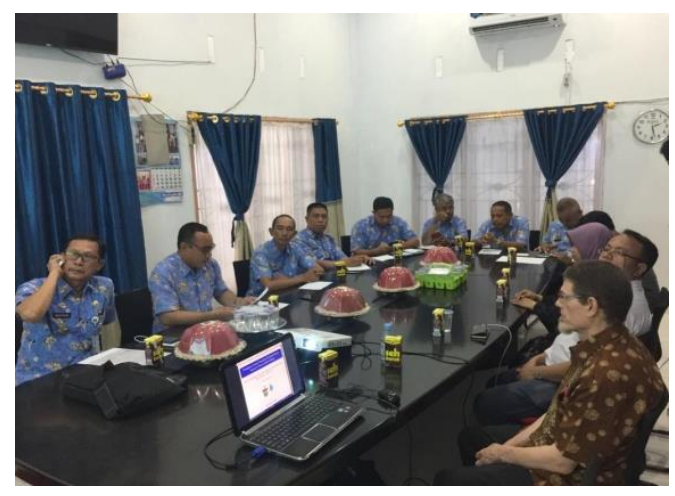

Gambar 2(c). Sosialisasi Awal

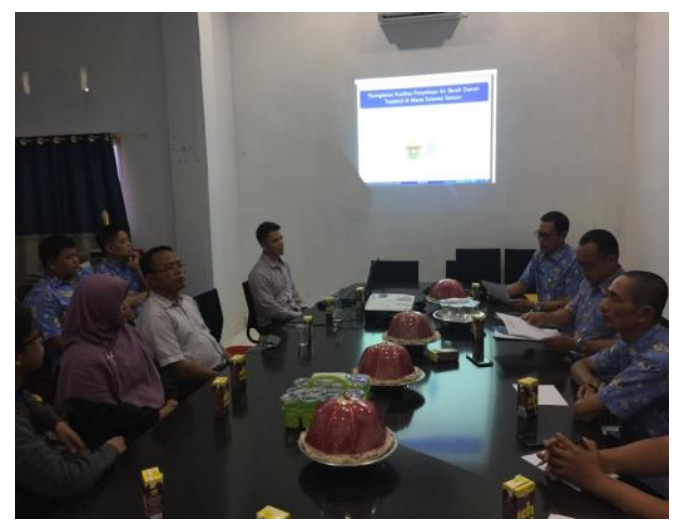

Gambar 2(e). Sosialisasi Awal

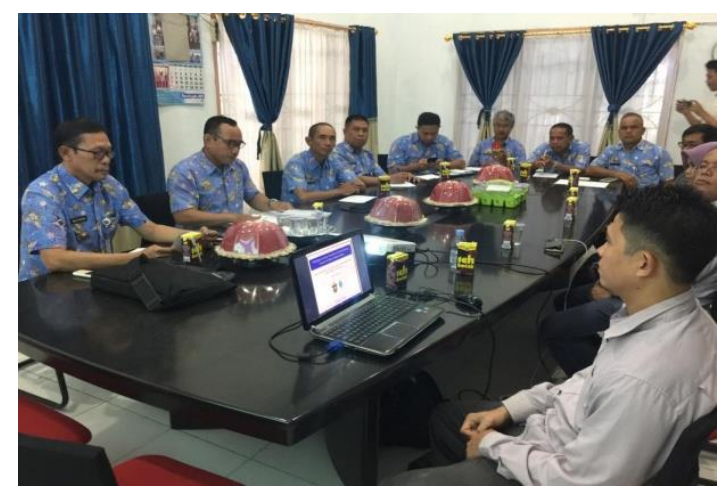

Gambar 2(d). Sosialisasi Awal

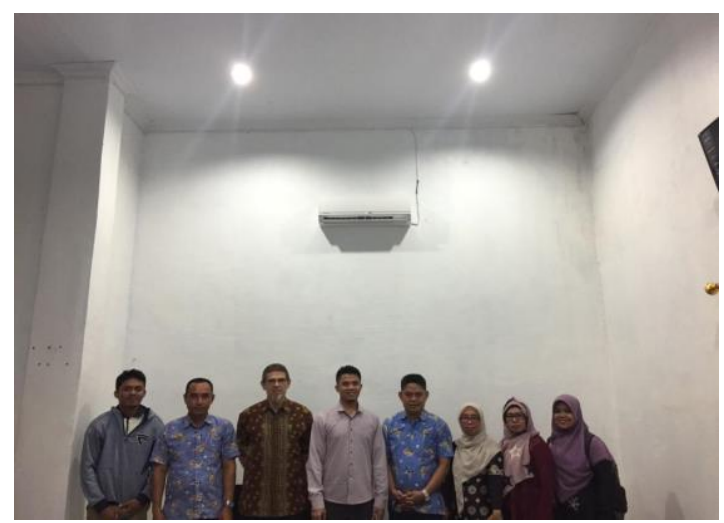

Gambar 2(f). Sosialisasi Awal

\section{Hasil dan Diskusi}

Proses sosialisasi menghasilkan beberapa hal penting terutama akan disepakatinya penetapan nota kesepahaman terkait anggaran desa yang diambil dari Anggaran Pembangunan Desa untuk digunakan dalam proyek QECeWaS 2 nantinya. Beberapa desa lainnya memperlihatkan antusiasme tinggi terkait pentingnya air bersih, dimana diantaranya salahsatu desa menganggarkan proses pipanisasi air yang bersumber dari gunung ke seluruh dusun yang berada pada desa tersebut.

\section{Kesimpulan}

Peninjauan lokasi dari Desa Nisombalia dan Bonto Bahari akan menjadi agenda lanjutan untuk melihat langsung dan menentukan titik lokasi pembangunan instalasi sistem desalinasi air bersih, yang akan mengubah air laut menjadi air siap konsumsi. Respon positif terhadap kegiatan proyek QECeWaS nantinya dapat berlangsung dengan lancar dan memacu desa lain untuk bergabung dalam kegiatan tersebut. 


\section{Ucapan Terima Kasih}

Ucapan terima kasih kepada Kepala Dinas Pemberdayaan Masyarakat Desa (PMD) Kabupaten Maros, Provinsi Sulawesi Selatan dan jajarannya yang telah memfasilitasi pelaksanaan kegiatan sosialisasi Proyek QECeWaS 2 yang menitikberatkan pada air bersih untuk konsumsi sehari-hari. Penghargaan yang setinggi-tingginya kepada Pemerintah Australia melalui hibah Australia Grant Scheme, 2018 round 2 yang telah mampu mendukung terlaksananya kegiatan awal dari Proyek QECeWaS 2. Ucapan terima kasih juga kepada kepala desa yang telah hadir pada saat sosialisasi terutama Kepala Desa Nisombalia dan Kepala Desa Bonto Bahari. Penghargaan yang setinggitingginya juga untuk anggota dosen dan tim teknis yang tergabung dalam riset grup Social, Cognitive Robotics and Advanced Artificial Intelligent Research Centre (CSAR 2AIR), Teknik Elektro UNHAS.

\section{Daftar Pustaka}

Anshar, M., Sadjad, R. S., Palantei, E., M., Zaenab., \& J., Dewiani. (2018). Pelatihan Perakitan Sistem Filterisasi Air Minum Skala Rumah Tangga. Technology for Society. JURNAL TEPAT: Applied Technology Journal for Community Engagement and Services, 1(1), 33-40. Retrieved from http://eng.unhas.ac.id/tepat/index.php/Jurnal_Tepat/article/view/1

Menteri Kesehatan Republik Indonesia (MENKES RI), (2010). Persyaratan Kualitas Air Minum. Peraturan Menteri Kesehatan Rebuplik Indonesia Nomor 492/Menkes/PER/IV/2010

Kucera, J. (2010). Reverse Osmosis: Design, Processes, and Applications for Engineers. Wiley Online Library. Viewed on 1 November 2018, Retrieved from https://onlinelibrary.wiley.com/doi/book/10.1002/9780470882634 